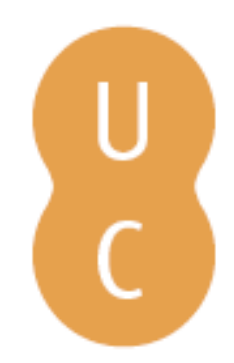

\title{
pombalina
}

\section{A lenda de Aríon e a influência de Plutarco na arte ocidental}

Autor(es): $\quad$ Ferreira, Luísa de Nazaré

Publicado por: Centro de Estudos Clássicos e Humanísticos; Imprensa da Universidade de Coimbra

URL

persistente: URI:http://hdl.handle.net/10316.2/31535

DOI: $\quad$ DOI:http://dx.doi.org/10.14195/978-989-8281-57-9_1

Accessed : $\quad$ 26-Apr-2023 15:54:41

A navegação consulta e descarregamento dos títulos inseridos nas Bibliotecas Digitais UC Digitalis, UC Pombalina e UC Impactum, pressupõem a aceitação plena e sem reservas dos Termos e Condições de Uso destas Bibliotecas Digitais, disponíveis em https://digitalis.uc.pt/pt-pt/termos.

Conforme exposto nos referidos Termos e Condições de Uso, o descarregamento de títulos de acesso restrito requer uma licença válida de autorização devendo o utilizador aceder ao(s) documento(s) a partir de um endereço de IP da instituição detentora da supramencionada licença.

Ao utilizador é apenas permitido o descarregamento para uso pessoal, pelo que o emprego do(s) título(s) descarregado(s) para outro fim, designadamente comercial, carece de autorização do respetivo autor ou editor da obra.

Na medida em que todas as obras da UC Digitalis se encontram protegidas pelo Código do Direito de Autor e Direitos Conexos e demais legislação aplicável, toda a cópia, parcial ou total, deste documento, nos casos em que é legalmente admitida, deverá conter ou fazer-se acompanhar por este aviso.

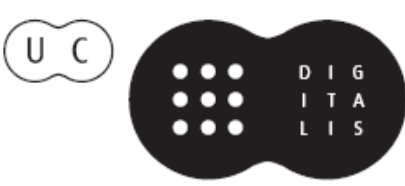


Colecção Autores Gregos e Latinos SÉRIE ENSAIOS

\section{Luísa de Nazaré Ferreira \\ Paulo Simôes Rodrigues Nuno Simões Rodrigues}

\section{Plutarco e as Artes}

Pintura, Cinema e Artes Decorativas

IMPRENSA DA UNIVERSIDADE DE COIMBRA COIMBRA UNIVERSITY PRESS 


\section{A lenda de Aríon e a influênCia de}

\section{Plutarco na ARTe Ocidental *}

Luísa de Nazaré Ferreira

(Universidade de Coimbra)

\section{Introdução: o golfinho na tradição clássica}

Há muitos séculos que o golfinho integra a galeria dos seres vivos mais amados pelos povos do Mediterrâneo e, quando pensamos na sua representação na cultura clássica, lembramo-nos imediatamente dos famosos frescos minóicos do palácio de Cnossos ${ }^{1}$. Os golfinhos surgem também com grande destaque no enigmático fresco em miniatura da «expedição naval» que decorava a sala 5 da Casa Ocidental do sítio arqueológico de Akrotiri, na antiga Tera (Santorini) ${ }^{2}$. Desde essa época

* Retomamos neste estudo a comunicação apresentada ao $8^{\circ}$ Congresso da International Plutarch Society (Universidade de Coimbra, 23-27 de Setembro de 2008), sob o título «Aríon e o golfinho: marcos literários e artísticos de uma aventura célebre (a propósito de Plu. Sept. sap. conv. 18.160E-19.162B)», a investigação sobre esta matéria que consta da nossa tese de Doutoramento (2005, 57-62) e de um artigo publicado no Boletim de Estudos Clássicos (49, 2008, 21-25). Em anexo (I), além de um poema atribuído a Aríon, citamos as versóes da lenda transmitidas por Heródoto (1.23-24) e Plutarco (O Banquete dos Sete Sábios 160E-162B), traduzidas, respectivamente, por José Ribeiro Ferreira e Delfim Ferreira Leão, a quem expressamos o nosso agradecimento.

${ }^{1}$ Cf. frescos dos golfinhos do «mégaron da Rainha», do Período Neopalaciano (1700 a.C.). Vide Preziosi, Hitchcock (1999) 94-95; http://commons.wikimedia.org/wiki/Image:Crete_knossos_ dolphins.jpg (acedido em 5/07/2010).

${ }^{2}$ Fresco da «expedição naval», de Tera, séc. XVI a.C. Atenas, Museu Nacional. Vide Karouzou (1992) 159, 162-163; 
remota, a presença deste animal torna-se recorrente na arte grega, em especial na pintura de vasos, e com a dupla função que estes dois exemplos ilustram: como simples motivo decorativo - testemunho da admiração que suscitava, da importância da natureza e do mar para os Gregos - e como convenção iconográfica para assinalar a paisagem aquática. Assim, na numismática, aparece habitualmente representado em moedas cunhadas nas cidades com uma forte ligação ao mar, designadamente da Magna Grécia³ .

De acordo com John Boardman (1974, 204), o golfinho é dos poucos animais marinhos que aparece com frequência na decoração do interior ou dos frisos das taças áticas de figuras negras. Um dos exemplos mais antigos é uma taça descoberta em Górdio (Turquia), assinada no exterior pelo pintor Clítias e pelo oleiro Ergotimo (c. 570 a.C.), e decorada no interior com três golfinhos e um peixe ${ }^{4}$. O golfinho é também um motivo ornamental nos skyphoi (vasos para beber) com bandas, fabricados na Ática em meados do século VI a.C. ${ }^{5}$ Merece igualmente destaque uma phiale (vaso para libaçóes), proveniente de Erétria, datada de c. 510-500 a.C., com

http://www.therafoundation.org/akrotiri/thewesthouse/ miniaturefriezeroom5flotilla/view (acedido em 5/07/2010).

${ }^{3}$ E.g. dracma de prata de Zancle, de c. 510 a.C.; tetradracma de prata de Siracusa, de c. 480-470 a.C. Vide Boardman (1990) 198, no 235 e 217 , no 257 , respectivamente.

${ }^{4}$ Berlim, Staatliche Museen (4604). Vide Boardman (1974) $n^{\circ} 108$.

5 Camberra, University House. Vide Boardman (1974) no 132 . 
representaçôes de golfinhos e polvos ${ }^{6}$, que é um belo exemplo do emprego da policromia (branco, vermelho) sobre fundo negro. Nesta técnica de pintura ("técnica de Six»), atestada por um grande número de phiales do final do século VI a.C., provenientes da Acrópole de Atenas, aparecem com frequência motivos marinhos (golfinhos, polvos, embarcaçóes) e florais, mas raramente personagen ${ }^{7}$.

É provavelmente mais conhecido um lécito ático de figuras negras sobre fundo branco, de c. 500 a.C., atribuído ao Pintor de Edimburgo, que representa Ulisses amarrado ao mastro do navio a escutar uma sereia que executa o duplo aulos pousada numa rocha (uma outra sereia toca lira). No meio destas personagens, um golfinho em plena acrobacia sugere que a cena decorre no alto-mar. A mesma função assumem os golfinhos que aparecem numa hydria ática de figuras vermelhas, atribuída ao Pintor de Berlim, de c. 500-480 a.C., onde vemos o deus Apolo, com a lira na mão, sentado sobre uma trípode elevada ${ }^{8}$. No entanto, se é evidente que os golfinhos estão aqui presentes porque evocam a paisagem marinha, não se pode excluir a ligação destes seres a várias divindades, designadamente ao deus que

6 Paris, Museu do Louvre (L 210). Vide http://commons. wikimedia.org/wiki/File:Phiale_Louvre_L210.jpg (acedido em 15/07/2010).

${ }^{7}$ Boardman (1974) 178-179. A designação de «técnica de Six» (Six's technique) foi adoptada por J. D. Beazley a partir do nome de Jan Six, o primeiro a descrevê-la. Cf. Boardman (1974) no 314, hoje em Viena, Kunsthistorisches Museen (1923).

${ }^{8}$ Respectivamente Atenas, Museu Nacional (CC958); Roma, Museus do Vaticano. Vide Boardman (1975) no 157. 
escolheu para seu espaço sagrado uma terra que se chamava Delfos, nome tão próximo da designação grega do golfinho ou delfim: delphis?.

A relação dos golfinhos com o deus do mar é clara (cf. e.g. Aristófanes, Cavaleiros 560; Ovídio, Fastos 2.81). De acordo com o hino a Poséidon atribuído ao poeta Aríon (vide infra), estes seres são de origem divina, porque foram gerados pela nereide Anfitrite (cf. vv. 1011). E a representação desta figura a ser transportada por um golfinho é um motivo da pintura de vasos sobretudo do final da Época Clássica ${ }^{10}$. A associação a Apolo, porém, parece ter tido um cunho religioso mais forte. No Hino Homérico a Apolo (III), o deus toma a forma de um golfinho para conduzir até às costas de Crisa os cretenses que escolheu para se tornarem sacerdotes do seu templo (vv. 388-439). Plutarco, em Sobre a inteligência dos animais 984A, observa que os Gregos ergueram templos em honra de Apolo Delfínio e que, ao contrário da versão do hino homérico, o deus não mudara de forma, mas enviara um golfinho a guiar os homens até ao porto de Delfos ${ }^{11}$.

9 Esta proximidade não assegura, todavia, uma relação etimológica, embora P. Chantraine observe que o epíteto Delphinios, atestado no Hino Homérico a Apolo 3.495, podia ser interpretado como "deus do delfim", mas também como "deus de Delfos» (Dictionnaire étymologique de la langue grecque. 1-2. Paris, Klincksieck, 1990, s.v. delphis).

${ }^{10}$ E.g. taça de figuras vermelhas do terceiro quartel do séc. IV a.C., proveniente da Itália do sul. S. Petersburgo, Museu do Hermitage. Vide http://www.hermitagemuseum.org/html_ En/04/2009/hm4_2_288_2.html (acedido em 15/07/2010).

${ }^{11} \mathrm{O}$ culto em honra de Apolo Delfínio é atestado por outras fontes, e.g. Hino Homérico a Apolo 3.495; Aristóteles, Constituição 
Da ligação deste animal ao deus do vinho e do teatro dão testemunho quer a literatura quer a pintura de vasos áticos, como documenta a célebre taça de figuras negras assinada por Exéquias c. 530 a.C. ${ }^{12}$ No exterior exibe o motivo dos olhos grandes, talvez inventado pelo próprio artista. A decoração do interior relaciona-se certamente, como julgam vários estudiosos, com o tema central do VIIo Hino Homérico, dedicado a Diónisos, que M. West $(2003,16)$ data do final da Época Arcaica. Nele se relata como o deus, confundido com um príncipe, foi raptado por piratas ${ }^{13}$. No entanto, estes assustam-se com os prodígios do filho de Zeus, atiram-se ao mar e são transformados em golfinhos (v. 53). Diónisos salvou deste destino o timoneiro que, desde o início, demonstrara grande piedade e se opusera, em vão, à violência dos companheiros (vv. 17-24). A metamorfose é assim, ao mesmo tempo, o castigo imposto aos homens que não foram capazes de detectar os sinais de divindade do passageiro acolhido a bordo, mas é também um símbolo de redenção,

dos Atenienses 57.3; Plutarco, Vida de Teseu 14.1. Vide Schamp (1976) 100-103.

12 Munique, Staatliche Antikensammlungen (2044). Vide Boardman (1974) 57-58, no 104; Robertson (1978) 71-72; Woodford (1986) 25-26, fig. 24; Moore (1987) 154-155; Boardman (2001) 283-284, no 309; http://commons.wikimedia.org/wiki/ File:Exekias_Dionysos_Staatliche_Antikensammlungen_2044.jpg (acedido em 15/07/2010).

${ }^{13}$ West (2003) 16 nota que Píndaro alude a este mito (fr. 236 Maehler) e supóe que o hino homérico não deve ter sido composto muito antes do tempo do poeta de Tebas, que terá nascido c. 518 a.C. Outros estudiosos não excluem uma data de composição mais antiga (séc. VII ou VI a.C.). Cf. Evelyn-White (1936) xxxviii-xxxix. 
uma vez que os poupa da morte e de uma vida de maldade.

A taça de Exéquias representa o deus do vinho reclinado majestosamente num barco cujo mastro sustenta (ou é ele próprio) uma magnífica videira, o que parece ser a ilustração de um dos prodígios referidos no hino homérico (vv. 38-42) ${ }^{14}$. À volta do barco, formando um círculo completo com os ramos da videira e os cachos de uvas, o artista dispôs sete golfinhos em harmoniosa simetria, uns voltados para a direita, outros para a esquerda, e assim concedeu à pintura a ilusão de movimento. Dois golfinhos muito mais pequenos figuram na decoração do barco que acolhe, à semelhança de um leito do symposion, o corpo reclinado do deus. Como bem notou M. H. Rocha Pereira (2009, 19), outro elemento singular desta composição é o branco da vela desfraldada, que se destaca do fundo vermelho da taça.

É bem possível, como supôs M. West (2003, 17), que a qualidade excepcional desta pintura tenha inspirado o mito e não o contrário ${ }^{15}$. Certo é que a peça

${ }^{14}$ «E logo, ao longo do bordo mais alto da vela, estendem-se / ramos de videira, daqui e dali, e pendem inúmeros / cachos. Em volta do mastro, negra, coleava uma hera, / a proliferar flores, e nela cresciam os gratos frutos. / Todos os escalmos tinham grinaldas. (...)» - Tradução de Ferreira (2006) 21-23.

${ }^{15} \mathrm{O}$ mito dos piratas transformados em golfinhos por Diónisos foi também referido na Biblioteca atribuída a Apolodoro (3.5.3), por Ovídio (Metamorfoses 3.581-691) e Higino (Fabulae 134, De Astronomia 2.17). Luciano evoca-o brevemente nos Diálogos dos deuses marinhos 5 . No séc. IV a.C., a lenda foi representada nos relevos do monumento corégico de Lisícrates, que celebrou a vitória como patrocinador dos espectáculos de teatro (choregos) no 
confirma que os golfinhos se tornaram a pouco e pouco elementos indissociáveis da paisagem marítima. Além desse motivo artístico, tal como o hino homérico, a pintura documenta a relação destes seres amistosos com Diónisos.

Se desde muito cedo surgiu entre os Gregos a ideia de que existe um vínculo especial entre os golfinhos e algumas divindades, a imagem do golfinho que salva das águas seres humanos e com eles cria laços de amizade, em especial com os mais jovens, torna-se familiar ao imaginário clássico pelo menos desde a Época Arcaica. Parece datar desse período uma estatueta em bronze, possivelmente votiva, proveniente das escavaçóes na Acrópole de Atenas, que representa um rapaz sobre o dorso de um golfinho ${ }^{16}$. O facto de este animal surgir na cultura clássica associado à ideia de salvação, habitualmente numa situação limite, explica que mais tarde, na iconografia cristá primitiva, venha a ser também entendido como representação simbólica da fé e, ainda que mais raramente, do Cristo Salvador ${ }^{17}$.

ano de 334 a.C. Vide Boardman (1995) 27, no 16.

16 Atenas, Museu Nacional (6626). Vide Karouzou (1992) 110.

${ }^{17} \mathrm{O}$ golfinho como símbolo cristão suscita várias interpretaçôes: o amor e a ternura que une os homens; o golfinho acompanha os barcos e pode representar Cristo que guia os crentes na sua fé; a velocidade dos golfinhos pode ser um símbolo do desejo com que os devotos se dedicam a Cristo, depois de o conhecerem; na arte cristã também é representado a transportar as almas dos mortos para o Além; ao lado de uma âncora ou barco simboliza a alma de Cristo ou a Igreja; o golfinho pode também evocar a história de Jonas (Jn 1.2), sendo assim um símbolo de ressurreição. Cf. Impelluso (2004) 305. 
Provavelmente com razão, defendem alguns estudiosos que este simbolismo deriva principalmente do relato do salvamento do poeta Aríon transmitido por Plutarco no Banquete dos Sete Sábios, que comentaremos adiante ${ }^{18}$.

\section{A lenda de Aríon na Antiguidade: fontes literárias e iconográficas}

Se nos demorámos nestas considerações iniciais é porque esta tradiçáo mitológica e iconográfica explica, em parte, a perenidade da história de Aríon como tema literário e artístico, bem como a variedade de tratamentos que suscitou ao longo de séculos. As fontes literárias mais importantes demonstram que esta lenda mistura, como tantas outras que nos chegaram da Antiguidade, elementos históricos e ficcionais. De facto, o retrato que nos apresenta Heródoto, a nossa fonte mais antiga e talvez mais influente, enquadra-se perfeitamente no contexto poético-musical da Época Arcaica (1.23-24):

- Aríon, natural da ilha de Lesbos (de Metimna), era um executante exímio da arte da cítara e teve um papel decisivo na evolução da forma coral do ditirambo ${ }^{19}$;

- Como se tornou costume na Época Arcaica, este artista fazia da mobilidade um modo de vida (e estava, assim, sujeito aos muitos perigos das viagens), embora tivesse uma relaçáo privilegiada com um patrono poderoso, Periandro, tirano de Corinto entre c. 625

${ }^{18}$ Vide J. Chevalier et A. Gheerbrant (1982), Dictionnaire des Symboles. Paris, Robert Laffont/Jupiter, s.v. dauphin.

19 No que respeita a este assunto, vide Privitera (1988), Zimmermann (1992) 24-29, Ieranò (1992), Ieranò (1997) 187-194, e o nosso estudo (2005) 57-62. 
e 585 a.C., que foi considerado um dos Sete Sábios ${ }^{20}$. Assim, o poeta teria desenvolvido a sua carreira no último quartel do século VII e início do século VI a.C., portanto, em data próxima de Safo e Alceu de Lesbos, e de Estesícoro de Hímera.

Estes dados são corroborados por testemunhos posteriores $^{21}$, mas a fama de Aríon deve-se muito mais ao relato do seu salvamento, que constitui, na verdade, o tema central da digressão de Heródoto sobre o protegido de Periandro.

O historiador começa por esclarecer que a aventura era contada pelos habitantes de Corinto e confirmada pelos de Lesbos $(1.23,1.24 .8)$, do que se depreende que evoca uma tradição popular, que pode ter tido origem num mito de carácter etiológico ou em antigos cultos coríntios ${ }^{22}$. De acordo com o seu relato, Aríon vivera a maior parte da vida na corte de Periandro, mas em determinada altura sentiu vontade de divulgar o seu talento na Magna Grécia e, depois de ganhar muito dinheiro, decidiu regressar a Corinto, a partir

${ }^{20}$ Aríon é o primeiro poeta grego a ser associado à protecção de um tirano, o que se tornará frequente a partir do séc. VI a.C. Periandro de Corinto figura entre os Sete Sábios nas listas transmitidas por Pausânias (10.24.1) e Diógenes Laércio (1.94100), mas não na de Platão (Protágoras 343a).

${ }^{21}$ Cf. Helânico de Lesbos (Lista das vitórias nas Carneias) e Dicearco (Sobre os concursos dionisíacos), citados num escólio de Aristófanes (ad Aves 1403). A Suda (A 3886) situa o floruit do citaredo de Lesbos c. 628/624 a.C. (a Crónica de Eusébio um pouco mais tarde: 619/618 ou 610/609, segundo a versão arménia). Cf. schol. Pind. Ol. 13.25. Os testemunhos sobre Aríon foram reunidos por Campbell (1991) 16-25.

${ }^{22}$ Cf. Bowra (1963) 131-134, Burkert (1983) 199-200; Defradas, Hani, Klaerr (1985) 341. 
de Tarento, num barco de marinheiros coríntios. Estes, porém, levados pela perfídia e pela ambição, projectam matar o ilustre citaredo atirando-o ao mar. Quando viu que as súplicas não os demoviam, Aríon pediu que o deixassem executar uma última melodia. Logo que terminou, lançou-se ao mar e um golfinho tomou-o no dorso e levou-o para o Ténaro, o promontório situado mais ao sul do Peloponeso (actual cabo Matapan). Assim que chegou a Corinto, dirigiu-se ao palácio e relatou a aventura a Periandro que mais tarde interrogou os marinheiros sobre o sucedido (1.24).

Um dos pontos altos da versáo de Heródoto é o momento em que Aríon actua pela última vez. Apresenta-se aos piratas com uma indumentária elaborada, como se participasse num ritual, e executa o nomos orthios, uma melodia citaródica famosa (geralmente em honra de Apolo) de grande exigência vocal $^{23}$. Heródoto insiste no pormenor das vestes solenes e ornamentadas, com as quais o poeta se atira ao mar (1.24.4-5) e, no final, se apresenta perante os piratas (1.24.7), confirmando que a ostentação e elegância do vestuário eram um elemento fundamental da actuaçáo e identidade dos citaredos e de outros cultores das Musas, como testemunham, em especial, os vasos áticos de figuras vermelhas ${ }^{24}$.

${ }^{23}$ Segundo o De musica $1140 \mathrm{~F}$, a melodia órtia havia sido inventada por Terpandro de Lesbos (séc. VII a.C.). A Suda (A 1701) corrobora esta informação e atesta que consistia num hino em honra de Apolo. Da popularidade dá testemunho Aristófanes, Cavaleiros 1279. Vide Gostoli (1993).

${ }^{24}$ E.g. Nova Iorque, The Metropolitan Museum of Art (56.171.38): ânfora atribuída ao Pintor de Berlim, c. 490 a.C. 
O historiador encerra a digressão observando que havia no Ténaro uma oferta votiva de Aríon, em bronze e de pequenas dimensóes, que representava um homem no dorso de um golfinho (1.24.8), monumento que terá sido ainda visto por Pausânias (3.25.7, cf. 9.30.2). Moedas cunhadas em Metimna, a terra natal do poeta, e em Tarento atestam a popularidade da lenda numa vasta área geográfica que vai do Mar Egeu à península itálica ${ }^{25}$.

A popularidade da aventura de Aríon deve-se a Heródoto e a outros autores, como Ovídio (Fastos 2.79-118), Plutarco (O Banquete dos Sete Sábios 160E-162B), Higino (Fabulae 194, De Astronomia 2.17), Luciano (DMar. 5), Aulo Gélio (Noites áticas 16.19, baseado em Heródoto) e Cláudio Eliano (Natureza dos animais 12.45$)^{26}$. Este último escritor, numa compilação de factos extraordinários sobre a fauna, a fim de documentar que os golfinhos são atraídos pelo canto e pelos sons do aulos, cita um dístico elegíaco, supostamente inscrito na estátua de Aríon erguida no Ténaro $^{27}$, e um hino em honra de Poséidon, que teria sido composto pelo poeta, mas que é, provavelmente,

(citaredo); Boston, Museum of Fine Arts (26.61): ânfora atribuída ao Pintor de Brigos, c. 480 a.C. (citaredo); Londres, British Museum (E 270): ânfora atribuída ao Pintor de Cleófrades, c. 490480 a.C. (lado A: rapsodo; lado B: auleta).

${ }^{25}$ Vide Richter (1984) 92-94, Cahn (1984) Arion 2-7, Ferreira (1994) 70 n. 32.

${ }^{26}$ Para um exame da transmissão literária da história de Aríon, vide Schamp (1976).

${ }^{27}$ Vide Page (1981) 499, anon. CLXXVII. Dois poemas da Antologia Grega (AP 9.308 e APl 276) atribuídos a Bianor (séc. I d.C.) atestam a perenidade da tradiçâao. 
uma composição dos fins do século $\mathrm{V}$ a.C. ou mais $\operatorname{tardia}^{28}$. Do talento artístico do citaredo de Metimna não nos chegou nenhuma prova segura. Como bem notou Cláudio Eliano (ibidem), este poema é um canto de agradecimento ao deus do mar e, ao mesmo tempo, retribui a gentileza dos golfinhos que salvaram Aríon. A ideia de que a "melodia sedutora dos auloi» chama a atenção destes animais já é referida num fragmento de Píndaro (fr. 140b.15-17 Maehler) ${ }^{29}$ e terá ecos na literatura da Época Clássica (e.g. Eurípides, Electra 435; Aristófanes, Rãs 1317). Na pintura de vasos, porém, o tema aparece muito mais cedo, como sugere uma taça ática de figuras negras, de c. 560-550 a.C., decorada no interior com três golfinhos, sendo que um tem braços e executa o duplo aulos ${ }^{30}$.

Plutarco introduz a lenda de Aríon no Banquete dos Sete Sábios através da figura de Gorgo, irmão de Periandro. De regresso de uma missão no Ténaro, anseia por contar um prodígio que ele próprio testemunhara (160D): no

${ }^{28} \mathrm{O}$ hino atribuído a Aríon integra actualmente os fragmenta adespota do corpus de poesia lírica grega (fr. $939 P M G$, em anexo). Vide Page (1962) 506-507, Campbell (1993) 360-363. Segundo este editor, trata-se de uma composição de estilo ditirâmbico de c. 400 a.C. (p. 361 n. 3). Para a análise da inscrição e do hino citados por Eliano, vide Bowra (1963) e Schamp (1976) 105-109, especialmente.

${ }^{29} \mathrm{O}$ fragmento de Píndaro foi transmitido por um papiro (P.Oxy. 408) e os vv. 15-17, que se referem à philomousia dos golfinhos, são citados por Plutarco nas Quaestiones convivales (704F-705A) e em De sollertia animalium (984B-C). Vide M Race (1997) 374-377.

30 Roma, Museo Nazionale di Villa Giulia (64698). Vide Lissarague (2000) 139, fig. 5.3. 
decurso de uma festa realizada à noite, à beira-mar, os celebrantes são surpreendidos pela chegada à praia de um grupo de golfinhos que se deslocavam em grande velocidade e transportavam uma figura humana. Logo descobrem que se trata de Aríon, pois, observa Gorgo, além de estar consciente, embora atordoado pela viagem, envergava os trajes que usava nas suas actuaçóes (160E-161B). A indumentária solene do poeta de Lesbos é um elemento relevante na digressão de Heródoto, pois permite denunciar a Periandro a falsidade do discurso dos piratas (1.24.7). No texto de Plutarco, porém, as vestes são os primeiros sinais da dimensão religiosa que envolve o seu salvamento. É que, como explicará Gorgo, quando Aríon se deu conta do perigo em que se encontrava teve uma espécie de inspiração divina que o levou a apresentar-se perante os seus assassinos envergando um traje solene, como se de uma veste fúnebre se tratasse, preparado para uma última actuação (161B-C). Também neste ponto o texto de Plutarco introduz uma ligeira diferença em relação a Heródoto, sublinhando a devoçáo religiosa do citaredo, quese propóe cantar o nomos pythicos, uma composição que evocava expressivamente a luta de Apolo contra a serpente Píton (cf. Schamp 1976, 116). Segue-se o momento fulcral desta versão, a descrição dos sentimentos e emoçôes que Aríon experimenta quando é erguido das águas, ainda antes de ter mergulhado completamente (161D). A pouco e pouco, convence-se de que se salvava por ser amado pelos deuses (theophiles aner) e que os golfinhos não eram mais do que intermediários da divindade 
(161E-162A). Na parte final da sua intervenção, Gorgo confirmará que o salvamento prodigioso do poeta era obra da intervenção divina (162B).

Por conseguinte, embora a influência de Heródoto esteja subjacente ao longo de todo o passo, não se trata agora de um conto popular transmitido pela tradição oral, mas de um acontecimento recente testemunhado por uma pessoa da confiança de Periandro. Ao dar a palavra a um dos convivas do banquete, Plutarco compôs uma versão mais pitoresca, que póe em destaque os momentos cruciais do salvamento de Aríon, designadamente a actuação perante os piratas e o transporte para terra, com todos os ornamentos, por um grande número de golfinhos velozes que se deslocam com movimentos sincronizados. É também evidente que nas Histórias de Heródoto a digressão sobre Aríon surge pela associação do famoso citaredo com Periandro ${ }^{31}$, enquanto no Banquete dos Sete Sábios a exposição de Gorgo é um testemunho emocionante da intervenção da divindade no mundo dos homens. Esta ideia será corroborada na parte final do tratado quando, após a narração de outras histórias extraordinárias sobre o comportamento amistoso dos golfinhos ${ }^{32}$, Anacársis

${ }^{31}$ Sobre as motivaçóes de Heródoto para narrar a história de Aríon, vide Hooker (1989); cf. Gray (2001); para uma análise do conteúdo filosófico-didáctico deste logos, vide Soares (2003) 96-101.

32 Sólon expôe o relato da morte de Hesíodo e como, graças aos golfinhos, o seu corpo, lançado ao mar pelos assassinos, foi resgatado e sepultado junto do templo de Zeus Nemeu (162C-F). Pítaco relata em seguida o salvamento de Énalo e da amada (163A-D). 
observar que as mais belas coisas se cumprem por vontade divina (163D).

A difusão da aventura de Aríon na Antiguidade deve-se em primeiro lugar a Heródoto, como notaram Estrabão (13.2.4) e Aulo Gélio (16.19.1), enquanto o papel da iconografia parece ter sido bastante menor, pois, além da numismática, a que já nos referimos, apenas nos chegaram representaçóes em mosaicos da Época Romana. Destaca-se, em especial, uma decoração da villa romana de Piazza Armerina (século IV d.C.) ${ }^{33}$, que podia ilustrar os versos de Ovídio (Fast. 2.115-116) sobre o momento em que Aríon é resgatado das águas:

ille sedens citharamque tenet pretiumque uehendi cantat et aequoreas carmine mulcet aquas.

Ele, sentado, segura a cítara e pelo favor do transporte canta e com seu canto acalma as águas do mar.

As duas histórias são evocadas em Sobre a inteligência dos animais 969E, 984D (Hesíodo), e 984E (Énalo, também em Ateneu $11.466 \mathrm{c}-\mathrm{d})$, num passo em que Plutarco relata outros salvamentos de pessoas por golfinhos. O escritor refere neste tratado (985B) que Estesícoro afirmava num poema (fr. 225 PMG) que o escudo de Ulisses ostentava um golfinho, pois segundo contavam os cidadãos de Zacintos este animal salvara o pequeno Telémaco de se afogar. Cf. Bowra (1963) 131-133, Campbell (1991) 157 n. 2, Van der Stockt (2005) 18-19.

${ }^{33}$ Mosaico de Aríon da Villa Romana del Casale de Piazza Armerina, Sićlia, séc. IV d.C. Vide Pe. Carmelo Capizzi S.J. et F. Galati (s/d), Piazza Armerina. Les mosäques et Morgantina. Bologna, Éditions Italcards, 50-51; http://www.villadelcasale.it/ (acedido em 6/07/2010). 


\section{A recepçáo da lenda de Aríon na arte} ocidental: alguns exemplos

$\mathrm{Na}$ cultura do Ocidente, a lenda do citaredo grego tornou-se muito popular sobretudo a partir do Renascimento, provavelmente desde que surgiram as primeiras ediçóes impressas das Histórias de Heródoto e do Banquete dos Sete Sábios de Plutarco. No que respeita a este autor, a editio princeps das Vidas Paralelas surge em Florença, em 1517, mas logo foi suplantada pela edição de Aldo Manúcio, saída em Veneza em 1519. Da editio princeps dos Moralia, impressa pelo mesmo em Veneza, em 1509, ocupou-se Demetrios Ducas (com a colaboração de Erasmo de Roterdão e Andreas Torresanus). Em 1572, Henri Etienne (Stephanus) publica em Paris a primeira ediçáo completa das obras de Plutarco. No entanto, para a sua divulgação foram fundamentais as traduçóes latinas e as versôes em língua vernácula. No que respeita às primeiras, muito numerosas no século $\mathrm{XVI}$, merecem destaque as realizadas por Xylander (Vitae, 1561; Moralia, 1570) e Cruserius (Vitae, 1564; Moralia, 1573). Quanto às segundas, a mais influente, designadamente no domínio das artes, foi a tradução francesa de Jacques Amyot (Vitae, 1559; Moralia, 1572). Baseia-se nesta versão a tradução inglesa das Vidas Paralelas, por Thomas North, publicada em 1579, que se tornou na principal fonte das peças de temática romana de Shakespeare. A primeira tradução inglesa completa dos Moralia foi realizada por Philemon Holland a partir do original 
grego, ainda que com influência de Amyot, e impressa em $1603^{34}$.

O tema do poeta Aríon salvo por um golfinho não foi tão influente na arte ocidental como os mitos sobre divindades e heróis da Antiguidade clássica. Mesmo assim, o catálogo organizado por Jane D. Reid em 1993 menciona cinquenta e oito obras, sendo a mais antiga a decoração a fresco dos tectos da Camera degli Sposi ou Camera Picta do Palácio Ducal de Mântua, realizada entre c. 1465 e 1474 por Andrea Mantegna (14311506), e a mais recente o livro The Dolphin, do poeta americano Robert Lowell (1917-1977), publicado em Nova Iorque em 1973 e vencedor do prémio Pulitzer.

Ainda que não seja exaustiva, esta compilação permite verificar que ao longo de seiscentos anos, a lenda de Aríon foi apreciada por pintores, escultores, compositores e escritores, em especial como alegoria do poder da poesia e da música sobre as forças e os seres da natureza. A gentileza dos golfinhos para com os humanos e a relação com o divino, que os elege como salvadores, bem como a atracção destes animais pela música são outros tópicos sedutores que vêm já

${ }^{34}$ Os dados aqui apresentados foram recolhidos essencialmente de Russell (1973) 143-158 e, em especial, de Pérez Jiménez (2008) 120-126, que examina em detalhe esta matéria. No que respeita às traduções realizadas nos séc. XIV e XV, vide Becchi (2010) 23-38, que regista três ediçóes do Banquete dos Sete Sábios, no período compreendido entre 1439 e 1452, pelos humanistas italianos Antonio Cassarino (1439-1447), Giovanni Aurispa (1440-1443) e Niccolò Perotti (1449-1452). 
da tradição clássica ${ }^{35}$, designadamente do Banquete dos Sete Sábios, onde Plutarco destaca, além da afeição aos homens (philanthropia) e à música (philomousia), o gosto dos golfinhos pelas acrobacias e brincadeiras com crianças $(162 \mathrm{~F}-163 \mathrm{~A})^{36}$.

Das obras referenciadas no catálogo de Jane D. Reid merece destaque um desenho realizado em 1514 por Albrecht Dürer (1471-1528), traçado com pluma e colorido com aguarela, que representa um Aríon jovem, nu, sobre o dorso de um enorme golfinho de aspecto monstruoso e pouco realista ${ }^{37}$. Dürer não será o único artista a imaginar o salvador do poeta como um animal fantástico ou de tamanho desmedido ${ }^{38}$. Já a nudez de Aríon, que confere à figura traços míticos, é sobretudo

35 Outras lendas antigas sobre a philanthropia dos golfinhos, particularmente em relação a crianças, foram transmitidas por vários autores gregos e latinos. Vide e.g. Plínio, o Antigo, Naturalis Historia 9.20-33 (em 9.28 detém-se em Aríon); Plínio, o Jovem, Epistula 9.33 (retoma a história mencionada pelo tio em $\mathrm{NH}$ 9.26, vide Stevens 2009); Aulo Gélio, além do relato de Heródoto sobre Aríon, recorda nas Noites áticas (6.8) uma outra "história extraordinária sobre o amor de um golfinho por um menino"; Cláudio Eliano, NA 2.6, 6.15, 8.3, 8.11; Ateneu 13.606c-f. Vide Higham (1960), Bowra (1963) 131 sqq., especialmente.

${ }^{36}$ Para o exame das referências a animais e, em especial, ao golfinho no tratado de Plutarco, vide Newmeyer (2009).

${ }^{37} \mathrm{O}$ desenho de Albrecht Dürer, que inclui a epígrafe Pisce super curvo vectus cantabat Arion («sobre o curvo peixe transportado cantava Aríon»), integra actualmente a colecção Graphische Sammlung Albertina (Viena de Áustria), segundo Impelluso (2004) 350. Os traços fantasiosos do golfinho contrastam com o realismo dos estudos da natureza que integram a mesma colecção e aproximam-se muito mais do desenho a pena que realizou em 1515 do Rinoceronte, hoje no Museu Britânico. Cf. Wolf (2006) 40, 55.

${ }^{38}$ Cf. e.g. a gravura Three Men of War in a Tempest Sailing to the Right, with Arion (1565), de Pieter Bruegel, o Velho (1525-1569). 
uma inovação relativamente à tradição literária mais influente, na qual, como vimos, as vestes de gala do citaredo têm grande importância.

Não sendo possível fazer aqui um estudo detalhado da recepção desta lenda grega, propomos agora uma breve análise de algumas obras que não figuram no catálogo acima referido, no sentido de mostrarmos a diversidade de tratamentos artísticos que ela inspirou.

Uma das evocaçóes mais antigas do citaredo de Lesbos encontra-se na tapeçaria $A$ ilha da Fortuna, da série As Honras, que foi realizada em lá, seda, prata e ouro, entre 1520 e 1525, na oficina de Pieter van Aelst, em Bruxelas, e pertence hoje ao Património Nacional de Espanha ${ }^{39}$. A Fortuna surge retratada sob a forma de uma mulher coroada, de olhos vendados, a montar um cavalo e ocupa o centro da peça, acima da roda da sorte que divide a tapeçaria em duas partes. À direita da Fortuna encontram-se os favorecidos, a quem distribui rosas, enquanto os miseráveis, à sua esquerda, são fustigados com pedras e com os raios de Hefestos. Entre estes podemos ver Átamas, Hécuba, Seleuco, a Paupertas (Pobreza), Cleópatra e Ápio Cláudio. Do lado oposto, protegidos por Febo Apolo, estão, entre outras figuras mitológicas e históricas, Polícrates, tirano de Samos,

${ }^{39}$ Segóvia, Palacio Real de La Granja de San Ildefonso, Museo de Tapices (série 8). O mercador e tapeceiro Pieter van Aelst já havia realizado, entre 1516 e 1519, a partir de cartóes de Rafael, a célebre armação Actos dos Apóstolos destinada à Capela Sistina, que lhe trouxe grande fama. A autoria dos cartóes de Los Honores é desconhecida, embora se suspeite que Bernard van Orley e Jan Gossart tenham colaborado na sua elaboração. Cf. Delmarcel (1999) 75, 78, 148; Campbell (2002) 184-185, 289. 
Rómulo e Remo, crianças, a serem amamentados pela loba, Dânae com o filho ao colo, Europa e o touro, Andrómeda prisioneira e Perseu (adulto) prestes a libertá-la. Aríon integra o grupo dos afortunados e surge no canto inferior a executar uma harpa sobre o dorso de um golfinho, envergando vestes sumptuosas, como é descrito nas fontes antigas. A tapeçaria mostra a ilha da Fortuna, à qual muitos tentam chegar atravessando o mar, mas nem todos com sucesso. Constitui a primeira de nove peças que representam alegoricamente as qualidades que um soberano deve possuir e os vícios que deve evitar (Fortuna, Prudentia, Virtus, Fides, Honor, Fama, Justitia, Nobilitas e Infamia, segundo a ordem proposta por G. Delmarcel, cf. Campbell 2002, 175), se quiser obter Glória, Nobreza e Honra, sem cair na Infâmia. As nove tapeçarias de Los Honores formam uma das mais importantes colecçôes flamengas e supóe-se que terá sido encomendada pela corte de Habsburgo para homenagear Carlos V, eleito em 1519 Imperador do Sacro Império Romano e coroado em 23 de Outubro de $1520^{40}$.

Verdadeira ostentação de riqueza e poder para os seus proprietários, testemunho inegável do talento dos mestres tapeceiros, em especial da Flandres, da Baixa Idade Média ao período Barroco a tapeçaria constituiu umas das formas de arte mais excepcionais da cultura europeia. Rivalizava com a pintura, foi por ela

40 No que respeita à encomenda, datação, fontes literárias e filosóficas, e análise iconográfica das famosas tapeçarias, vide especialmente Delmarcel (1999) 147-154, Campbell (2002) 175-185, 288-290, com ilustrações e referências bibliográficas. 
influenciada e inspirava-se nas mesmas fontes: os textos bíblicos, os autores greco-latinos, a mitologia clássica e os episódios mais célebres da História antiga. No entanto, raramente conseguimos ter certezas sobre as fontes literárias ou iconográficas de determinada peça ou série, como é o caso de Los Honores (cf. Delmarcel 1999, 148, Campbell 2002, 184). Sabemos, porém, que algumas tapeçarias se baseiam em Plutarco e apresentamos, como anexo a este trabalho (II), uma breve nota sobre essa influência.

Alguns anos após a coroação de Carlos $\mathrm{V}$ foi impresso em 1531 na Alemanha, em Augsburgo, o Emblematum liber, do milanês Andrea Alciato (ou Alciati, 1492-1550), que viria a ter grande repercussão na Europa ocidental e contribuiu para a difusão de muitos temas greco-latinos, designadamente no que respeita à interpretação alegórica e moralizadora deste legado clássico (cf. Hallyn 1993, 315-319). Publicado originalmente em latim, o livro de Alciato conheceu durante a vida do autor várias ediçóes revistas (o número total de emblemas fixou-se em 212), foi muito traduzido e imitado, tendo exercido uma influência notável no domínio das artes, em especial nos séculos XVI e XVII. Na edição de 1536, saída em Paris, o título mudou para Emblematum libellus e a obra vulgarizou-se como Emblemata. O termo emblema recupera da noção greco-latina a alusão a um trabalho artístico e, mais do que um simples poema, distingue-se pela combinação de três elementos: uma sentença ou um provérbio (mote, lema ou inscriptio), uma gravura, alusiva ao tema 
ou objecto (pictura, icon, symbolon) e um epigrama ou texto em prosa, de carácter explicativo (subscriptio) ${ }^{41}$.

A lenda de Aríon salvo por um golfinho figura no livro de Alciato desde as primeiras impressôes (emblema $\mathrm{XC)}$ com o mote In avaros, vel quibus melior conditio ab extraneis offertur ("Contra os gananciosos ou para os que recebem melhor trato de estranhos»), que se manteve nas ediçóes posteriores, e com o seguinte epigrama ${ }^{42}$ :

Delphini insidens vada caerula sulcat Arion,

Hocque aures mulcet, fraenat et ora sono.

Quam sit avari hominis, non tam mens dira ferarum est:

Quique viris rapimur, piscibus eripimur.

No dorso do delfim Aríon sulca as cerúleas águas,

encanta os ouvidos da criatura e refreia a sua boca com este [som.

Não é táo selvagem a mente das feras como é a de homens [gananciosos. Quando homens nos raptam, peixes nos resgatam.

A gravura, que foi variando ligeiramente de edição para edição, retrata dois momentos do salvamento: em primeiro plano, no qual surge em destaque o golfinho com a boca muito aberta, de aspecto

${ }^{41}$ Amaral Jr. (2005) 7-11; B. F. Scholz (2007), in M. Landfester (ed.), Brill's New Pauly, Encyclopaedia of the Ancient World, Classical Tradition. Vol. II. Leiden: Brill, 165-169, s.v. Emblems.

${ }^{42}$ Vide o site Alciato's Book of Emblems. The Memorial Web Edition in Latin and English, que reproduz o texto latino e as imagens da edição de 1621 (Pádua, P. P. Tozzi, 152a ed.): http:// www.mun.ca/alciato/090.html (acedido em 15/07/2010). 
ameaçador e formas monstruosas, os marinheiros de uma embarcação (do tempo de Alciato) lançam ao mar uma pessoa; em segundo plano, entre a linha do navio e a do horizonte, vê-se Aríon, a salvo, sobre o dorso do golfinho a executar a sua harpa. A representação fantasiosa do cetáceo (identificado como "peixe»), o formato do instrumento musical e a concepção geral da imagem faz lembrar o desenho que Albrecht Dürer realizou em 1514 e supomos que possa ter sido por ele influenciado. É legítimo pensar que o livro de Alciato e as sucessivas traduçóes tenham também contribuído para a popularidade da história de Aríon. Na tradução francesa dos Emblemata publicada em Paris em 1584 (ed. Jean Richer, trad. Claude Mignault), a subscriptio inclui, além do epigrama acima citado, um texto em prosa com a observaçáo de que o emblema se inspira num epigrama de Bianor (Antologia Palatina 9.308) ${ }^{43}$. Em três dísticos elegíacos o poeta grego recorda os dados principais do mito e encerra com uma pergunta retórica: «Teria, então, o mar peixes mais justos do que os homens?». É provável, porém, que Alciato se tenha baseado noutras fontes literárias e iconográficas ${ }^{44}$.

Voltamos ao domínio das artes decorativas para destacar uma obra que merece certamente a nossa atenção e foi estudada com grande detalhe por Victor Jabouille em 1985: uma colcha bordada do

${ }^{43}$ Vide a informação disponível no site French Emblems at Glasgow: http://www.emblems.arts.gla.ac.uk/french/emblem. php?id=FALc089 (acedido em 15/07/2010).

44 Para uma análise mais detalhada desta questão, vide Pérez Jiménez (2005). 
século XVII, de fabrico indo-português, que integra as colecçóes do Museu Nacional de Arte Antiga (inv. 2237) e é considerada um dos melhores exemplares deste tipo de trabalho ${ }^{45}$. Confeccionada em algodáo branco bordado a seda selvagem (tussah, menos suave e brilhante do que a seda natural), em ponto de cadeia, de margarida e nó, esta peça tinha a função de decorar uma cama e, à semelhança de outras colchas do mesmo género, combina temas bíblicos com mitos clássicos (neste caso a história de Aríon e de Hércules, em especial), com a mitologia hindu e cenas da vida quotidiana (designadamente de caça). Trata-se, portanto, de um artefacto que é fruto da síntese de dois legados - o judaico-cristáo e o greco-romano - e do contacto de duas culturas: a europeia/ocidental e a indiana/oriental.

A história de Aríon é contada em dezasseis quadros dispostos à volta do painel central rectangular, que representa a Justiça de Salomáo - um episódio bíblico recorrente nas colchas indo-portuguesas ${ }^{46}-$, e pode ser resumida do seguinte modo:

(1) Os rios, os seres da natureza e os homens imobilizavam-se para escutar o canto sedutor de Aríon (1-7);

(2) Durante a viagem de regresso à pátria, é

45 Vide http://www.matriznet.imc-ip.pt/ipm/MWBINT/ MWBINT00.asp (acedido em 15/07/2010).

${ }^{46}$ Cf. e.g. a colcha indo-portuguesa dos sécs. XVI-XVII, tecida em linho e bordada a fio de seda amarelo, do Museu Nacional Machado de Castro (inv. 6984). Vide F. Alves e P. Ferrão (2005), "Arte dos tecidos e dos bordados», in A. Alarcáo (coord.), Museu Nacional Machado de Castro. Roteiro. Lisboa, IPM, 140, 151. 
ameaçado de morte pelo timoneiro e, após uma última actuação, lança-se ao mar (8-11);

(3) É salvo por um golfinho, que suscita a piedade dos deuses, pelo que Júpiter (identificado pela águia) o recompensa, colocando-o no céu entre as estrelas.

As cenas, dispostas em faixas, sucedem-se segundo um esquema que se aproxima da banda desenhada. A decoração destas colchas é, portanto, narrativa e as figuras surgem habitualmente caracterizadas à moda portuguesa do início do século XVII. Aríon aparece assim a executar um instrumento musical que pode ser um alaúde, mas que náo tem nada a ver com a cítara antiga nem com a harpa que aparece no desenho de Albrech Dürer ou na tapeçaria $A$ ilha da Fortuna. Já o golfinho é uma criatura híbrida, com focinho de mamífero e grandes escamas no resto do corpo. À semelhança das obras comentadas anteriormente, as suas formas são completamente fantásticas. Uma análise mais cuidada das dezasseis cenas confirma que esta história de Aríon não se baseia em Heródoto nem em Plutarco, mas segue de muito perto a versão dos Fastos de Ovídio (2.79-118). De facto, se a $14^{\mathrm{a}}$ cena - na qual vemos Aríon a executar o instrumento musical sobre o dorso do golfinho - ilustra bem os vv. 115-116 acima citados, as duas últimas cenas não podiam estar mais próximas destas palavras finais (vv. 117-118):

di pia facta uident: astris delphina recepit Iuppiter et stellas iussit habere nouem. 
Os deuses vêem os feitos piedosos: entre os astros o golfinho [recebeu Júpiter e quis que tivesse nove estrelas.

O golfinho é colocado no céu e recebe como séquito as estrelas que constituem a constelação Delphinus (Delfim, Golfinho) do hemisfério norte, uma das que foi identificada na Antiguidade.

Segundo Teresa P. Pereira, uma colcha muito semelhante, existente no Museo Nazionale del Palazzo di Venezia, em Roma, cuja decoração se baseia igualmente nas temáticas clássicas principais da peça do Museu Nacional de Arte Antiga, inclui legendas em português e numa lê-se «Fábula jocosa conta Ovídio» (Pereira e Alarcão 1988, 9-11). Como é sabido, o poeta latino foi um dos principais transmissores dos temas clássicos e, além da sua popularidade, quer na Idade Média quer no Renascimento, as ediçóes das suas obras eram também as mais ilustradas, tendo sido fonte de inspiração de muitos escritores e artistas ${ }^{47}$. É plausível, por isso, que os modelos visuais das colchas indo-portuguesas remontem às ilustraçóes das suas obras, como tem sido sugerido (Jabouille 1985, 59; Pereira 1988, 11). O destaque dado à lenda de Aríon e à saga dos trabalhos de Hércules, além da presença menos relevante de

${ }^{47}$ Vide e.g. A. Monteverdi (1959), «Ovidio nel Medio Evo», in F. Arnaldi et alii, Studi Ovidiani. Roma, Istituto di Studi Romani Editore, 63-78; N. Lascu (1959), "La fortuna di Ovidio dal Rinascimento ai tempi nostri», ibidem, 79-112; E. K. Rand (1963), Ovid and his Influence. New York, Cooper Square Publishers, 108-156; S. Viarre (1976), Ovide. Essai de lecture poétique. Paris, Les Belles Lettres, 117-137. 
muitas outras figuras da mitologia greco-latina, não é exclusivo destas duas peças, já que são temáticas recorrentes nas colchas bordadas indo-portuguesas. Ao analisar as razóes da popularidade da história de Aríon nas suas decoraçóes e na época em que foram fabricadas (a dos Descobrimentos), V. Jabouille (1985, 54-55) sublinhou os seguintes aspectos: em primeiro lugar, o enaltecimento da poesia (e da arte em geral), que justifica o salvamento do poeta por intermédio do golfinho, ser ligado a Apolo, o protector das artes; por outro lado, a familiaridade da temática náutica, em especial os perigos das viagens por mar, bem como a própria caracterização de Aríon, o homem que procura o seu sustento longe da pátria, enriquece graças ao seu trabalho e talento, atravessa dificuldades, mas é salvo, porque os deuses o protegem; finalmente, pode também ter tido influência a simbologia associada ao golfinho como representante do Cristo Salvador.

A colcha bordada indo-portuguesa é um artefacto singular, ainda pouco estudado, ao que parece, e não deixa de ser extraordinário que tenha valorizado uma temática que na Antiguidade teve tão poucas representaçôes iconográficas. As «notas interpretativas» que V. Jabouille nos deixou sobre esta peça do Museu Nacional de Arte Antiga são um excelente ponto de partida para o seu conhecimento.

Ao contrário do que habitualmente acontece com os temas clássicos, a lenda de Aríon não tem sido fértil no domínio da pintura, mas verifica-se uma grande 
variedade de tratamentos ${ }^{48}$. Chamamos brevemente a atenção para um óleo sobre madeira de Gustave Moreau (1826-1898). A poesia foi uma das temáticas mais importantes da carreira deste artista francês táo influenciado pelos temas greco-romanos e precursor da estética simbolista ${ }^{49}$. A obra Arion, porém, pintada em 1891 e hoje conservada no Museu do Petit Palais de Paris, é das menos conhecidas ${ }^{50}$. No pensamento de Moreau, a arte não devia ser uma ilustração pura dos textos, mas somente abrir o caminho à imaginação e à seduçáo dos sentidos. Neste quadro, a figura colorida e exótica de Aríon levado sobre as águas por um majestoso golfinho destaca-se de uma paisagem sombria que lembra cenários renascentistas. $\mathrm{O}$ poeta salvo in extremis, graças ao seu dom, não cessa de cantar mesmo durante o salvamento. Os trajes ornamentados e a cítara na mão evocam uma imagem que parece

${ }^{48}$ Um dos mais invulgares é uma obra de Francesco Bianchi Ferrari (c. 1460?-1510), que retratou Aríon sobre um golfinho como um menino nu: Arion riding on a Dolphin (c. 1509-1510). University of Oxford, Ashmolean Museum (A733). Vide http:// www.ashmolean.info/ash/objects/paintings/WA1947.243.php. Mais conhecido éo óleo sobre tela de François Boucher (1703-1770): Arion on the Dolphin (1748). Princeton University Art Museum (y1980-2). Vide http://artmuseum.princeton.edu/art/collections/ european/search/. William-Adolphe Bouguereau (1825-1905) alterou os dados do mito ao compor Arion sur un cheval marin (1855). The Cleveland Museum of Art (1980.238). Vide http:// www.clevelandart.org/ (sites acedidos em 15/07/2010).

${ }^{49}$ Veja-se o nosso estudo (2009), «A herança clássica na pintura de Gustave Moreau. O tema de Safo», Boletim de Estudos Clássicos 51, 111-116, com referências bibliográficas.

${ }^{50}$ Petit Palais, Musée des Beaux-Arts de la Ville de Paris (inv. PPP00754). Vide http://www.petitpalais.paris.fr/fr/collections/ arion (acedido em 15/07/2010). 
sair directamente do texto de Plutarco, mas a pintura transmite a impressão de que esta personagem é mais lendária do que real, mais divina do que humana, como se não fosse mais do que uma metáfora da inspiração poética. A magnificência da figura de Aríon, na qual sobressaem os tons avermelhados da indumentária e a ornamentaçáo do instrumento musical, aproxima-se grandemente das composiçóes sobre Safo, que o pintor tratou sobretudo entre 1867 e $1884^{51}$. É possível que a semelhança não seja casual, porque um dos temas que mais seduziu Gustave Moreau foi precisamente o suicídio da poetisa de Lesbos, que parece ser sobretudo uma metáfora da perda da inspiração poética. Aríon, porém, é resgatado pelo animal divino, graças ao seu canto e graças ao qual continuará a viver.

O catálogo de Jane D. Reid termina em 1973, mas desde essa data outras obras retomaram a história do salvamento de Aríon. Uma das mais recentes de que temos conhecimento é a ópera Arion \& the Dolphin, encomendada pela English National Opera e estreada em Junho de 1994. Com música composta por Alec Roth e libreto do escritor inglês de origem indiana Vikram Seth, desenvolve as linhas principais da lenda clássica em nove cenas, desde a partida de Aríon da corte de Periandro até ao seu regresso a Corinto. Esta versão dá grande relevo à philanthropia e philomousia dos golfinhos, para daí retirar uma mensagem de

${ }^{51}$ Cf. e.g. a aguarela Sapho sur le rocher (1871-1872). Londres, Victoria and Albert Museum (P.11-1934). Vide http://collections. vam.ac.uk/item/O16435/watercolour-sappho/ (acedido em 15/07/2010). 
sentido universal: o valor da amizade. O título deriva em particular da VIa Cena, quando o citaredo é resgatado por um golfinho que consegue falar e cantar. Aríon, que até então era um jovem aclamado pelo seu talento, mas triste e solitário, recupera, graças à amizade e simpatia deste ser táo especial, a vontade de viver. A evocação das fontes clássicas, designadamente de Plutarco, é especialmente notória nesta VIa Cena, da qual merece a pena citar um excerto (Seth 1994, 44-46):

\section{DolPHIN:}

Icadius, Iapys' Cretan brother,

Shipwrecked, was guided by

A dolphin to Delphi;

And from that dolphin Delphi got its name:

Apollo and the dolphin were the same.

Or when Enalus saw his lover slung

Into the sea to calm the waves he flung

Himself into the waves that they might be

United constantly

A dolphin saved him, and its mate his mate

From their too-fluid fate. (...)

Arion:

What joyful lives you dolphins lead

Both when you mate and when you feed.

Compare it to my own condition -

A poor, unhappy, flipperless musician.

DoLPHIN:

Oh, no - 
You interest us, we interest you.

And we can tell who's who.

And we like music too.

We have our ancient musical traditions.

That's why we are susceptible to musicians.

Perhaps we should sing together after supper.

You take the lower part, I'll take the upper. (...)

Arion:

The days pass one by one.

I feel my life has only just begin -

And, for the first time, I am having fun!

Arion and Dolphin:

In air and water both, our voices part and blend, And I/you, who never sought a friend Have found one in the end.

Do libreto de Vikram Seth fez-se uma adaptação para crianças com ilustraçóes de Jane Ray (London, Orion, 1994). A história da amizade entre um músico e um golfinho desperta naturalmente a atenção dos mais novos, pelo que a aventura de Aríon figura também entre os temas favoritos da literatura infantil.

Em conclusão, esta história, que contém a dose necessária de maravilhoso e de verosimilhança, continua a inspirar os escritores e artistas do nosso tempo, provando a vitalidade dos temas greco-romanos. A imagem majestosa do poeta de Lesbos, o poder encantatório da sua arte, a philanthropia e philomousia dos golfinhos, o salvamento concebido como manifestaçáo 
da providência são alguns dos elementos que têm sido privilegiados e que já eram fundamentais na versão de Heródoto e muito especialmente na de Plutarco. 


\section{BibLIOGRAFia}

\section{EDIÇÓES, COMENTÁRIOS E TRADUÇÓES}

Campbell, D. A. (1991), Greek Lyric III. Cambridge, Mass., Harvard University Press.

Campbell, D. A. (1993), Greek Lyric V. Cambridge, Mass., Harvard University Press.

Defradas, J., Hani, J., Klaerr, R. (1985), Plutarque. Oeuvres Morales. Tome II. Paris, Les Belles Lettres.

Evelyn-White, H. G. (1936), Hesiod, Homeric Hymns, Epic Cycle, Homerica. Cambridge, Mass., Harvard University Press.

Ferreira, J. R., Silva, M. F. (1994), Heródoto. Histórias: livro $1^{\circ}$. Introdução geral de $\mathrm{M}$. H. Rocha Pereira. Introdução ao Livro I, versão do grego e notas de J. R. Ferreira (1.1-94) e de M. F. Silva (1.95-216). Lisboa, Ediçóes 70.

Ferreira, J. R. (2006), Espelho da Alma. O vinho na poesia grega. Antologia de textos. Anadia, Museu do Vinho.

Frazer, J. G. (1989, 2a ed.), Ovid. Fasti. Revised ed. by G. P. Goold. Cambridge, Mass., Harvard University Press.

Hude, C. (1927, 3a ed.), Herodoti Historiae. 2 vols. Oxford, Clarendon Press. 
Leâo, D. F. (2008), Plutarco. Obras Morais. O Banquete dos Sete Sábios. Tradução do grego, introdução e notas. Coimbra, CECH.

Maenler, H. (1989), Pindari Carmina cum Fragmentis. Pars II: Fragmenta, Indices. Leipzig, Teubner. [Maehler]

Page, D. L. (1962), Poetae Melici Graeci. Oxford, Clarendon Press. [PMG]

- (1981), Further Greek Epigrams. Cambridge, University Press.

Paton, W. R. (1974), Plutarchi Moralia I. Leipzig, Teubner.

Race, W. H. (1997), Pindar II. Cambridge, Mass., Harvard University Press.

Seth, V. (1994), Arion \& the Dolphin. A libretto. London, Phoenix House.

West, M. L. (2003), Homeric Hymns. Homeric Apocrypha. Lives of Homer. Cambridge, Mass., Harvard University Press.

\section{Estudos}

Amaral JR., R. (2005), Emblemática Lusitana e os Emblemas de Vasco Mousinho de Castelbranco. Introdução, transcrição e arranjo gráfico. Lisboa, Centro de História da Universidade de Lisboa.

Aulotte, R. (1965), Amyot et Plutarque: la tradition des Moralia au XVI siècle. Genève, Droz. 
Becchi, F. (2010), «El redescubrimiento de Plutarco en la edad del Humanismo», in A. Pérez Jiménez (ed.), Plutarco Renovado. Importancia de las Traducciones Modernas de Vidas y Moralia. Málaga, Grupo Editorial 33, 23-38.

Boardman, J. (1974), Athenian Black Figure Vases. A Handbook. London, Thames \& Hudson.

— (1975), Athenian Red Figure Vases. The Archaic Period. London, Thames \& Hudson.

— (1990, 4a ed.), The Greeks Overseas. Their Early Colonies and Trade. London, Thames \& Hudson.

— (1995), Greek Sculpture. The Late Classical Period and Sculpture in Colonies and Overseas. A Handbook. London, Thames \& Hudson.

- (2001), The History of Greek Vases. Potters, Painters and Pictures. London, Thames \& Hudson.

Bowra, C. M. (1963), «Arion and the Dolphin», $M H$ 20.3, 121-134 (= On Greek Margins, Oxford, Clarendon Press, 1970, 164-181).

Burkert, W. (1983), "The Return of the Dolphin», in Homo Necans. The Anthropology of Ancient Greek Sacrificial Ritual and Myth. Berkeley, University of California Press, 196-204.

CaHn, H. A. (1984), in Lexicon Iconographicum Mythologiae Classicae (LIMC). München, Artemis, II.1: 602-603, II.2: 434-435 (s.v. Arion). 
Campbell, T. P. (2002), Tapestry in the Renaissance. Art and Magnificence. New York, The Metropolitan Museum of Art.

Delmarcel, G. (1999), La tapisserie flamande du XV au XVIII siècle. Paris, Imprimerie Nationale.

Ferreira, L. N. (2005), Mobilidade poética na Grécia antiga. Uma leitura da obra de Simónides. Coimbra, Faculdade de Letras da Universidade de Coimbra.

_ (2008), «O canto de Aríon de Metimna (fr. adesp. 939 PMG)», Boletim de Estudos Clássicos 49, 21-25.

García Arranz, J. J. (1996), «La recepción de los escritos animalísticos de Plutarco en los libros de emblemas europeos durante los siglos XVI y XVII", in J. A. Fernández Delgado \& F. Pordomingo Pardo (eds.), Estudios sobre Plutarco: aspectos formales. Madrid, Ediciones Clásicas, 487-500.

Gostoli, A. (1993), «Il nomos citarodico nella cultura greca arcaica», in R. Pretagostini (ed.), Tradizione e innovazione nella cultura greca da Omero all'Età Ellenistica. Vol. I. Roma, Gruppo Editoriale Internazionale, 167-178.

Gray, V. (2001), «Herodotus' Literary and Historical Method: Arion's Story (1.23-24)», AJP 122, 11-28. 
Hallyn, F. (1993), "Mythe et embleme», in L. R. S. Tarugi (ed.), Il mito nel Rinascimento. Milano, Nuovi Orizzonti, 314-325.

Higham, T. F. (1960), «Nature Note: Dolphin-riders», $G \nLeftarrow R 7,82-86$.

Hooker, J. T. (1989), «Arion and the Dolphin», $G \& R$ $36.2,141-146$.

Ieranò, G. (1992), «Arione e Corinto», QUCC 41.2, $39-52$.

_- (1997), Il ditirambo di Dioniso. Le testimonianze antiche. Pisa-Roma, Istituti Editoriali e Poligrafici Internazionali.

Impelluso, L. (2004), Nature and Its Symbols. Los Angeles, The J. Paul Getty Museum.

JABouille, V. (1985), «Temática clássica na decoração de uma colcha indo-portuguesa do século XVII», Revista da Faculdade de Letras da Universidade de Lisboa 3, 47-62.

Karouzou, S. (1992), Musée National. Guide Illustré du Musée. Atenas, Ekdotike Athenon S.A.

Lissarague, F. (2000), «Aesop, Between Man and Beast: Ancient Portraits and Illustrations", in B. Cohen (ed.), Not the Classical Ideal. Athens and the Construction of the Other in Greek Art. Leiden, Brill, 132-149. 
Mathieu, P.-L. (1994), Gustave Moreau. Paris, Flammarion.

Mendonça, M. J. (1983), Inventário de tapeçarias existentes em museus e palácios nacionais. Lisboa, Instituto Português do Património Cultural.

Moore, M. B. (1987), «The Amasis Painter and Exekias: Approaches to Narrative», in Papers on the Amasis Painter and his World. Malibu, The J. Paul Getty Museum, 153-167.

Newmeyer, S. T. (2009), "Animal Philanthropia in the Convivium Septem Sapientium", in J. R. Ferreira, D. Leão, M. Tröster \& P.

B. Dias (eds.), Symposion and Philanthropia in Plutarch. Coimbra, Classica Digitalia/CECH, 497-504.

Pereira, T. P., Alarcão, T. (1988), Fábulas bordadas. Uma colcha indo-portuguesa do século XVII. Lisboa, Museu Nacional de Arte Antiga.

Pérez Jiménez, A. (1990), «Plutarco y el Humanismo Español del Renacimiento», in A. Pérez Jiménez \& G. del Cerro Calderón (eds.), Estudios sobre Plutarco: obra y tradición. Málaga, Sociedad Española de Plutarquistas, 229-247.

(2002), «Orientaciones y aproximación bibliográfica al proyecto ' $\mathrm{La}$ recepción de Plutarco desde la Antigüedad hasta el siglo XVII'», in Plutarchus Redivivus. Memorandum 
del II Encuentro de la Red Temática de Plutarco (Málaga, 14-15 de junio de 2001) y Propuesta de Proyectos aprobados. Málaga, Universidad de Málaga, 27-71.

_ (2005), «Plutarco en Alciato, I», Silva 4, 235-266.

- (2008, $1^{\mathrm{a}}$ ed. 1985), «4. Fortuna de Plutarco», in Vidas Paralelas I. Introducción general, traducción y notas. Madrid, Editorial Gredos, 105-131.

— A. ed. (2010), Plutarco Renovado. Importancia de las Traducciones Modernas de Vidas y Moralia. Málaga, Grupo Editorial 33.

Preziosi, D., Нiтchсоск, L. A. (1999), Aegean Art and Architecture. Oxford, University Press.

Privitera, G. A. (1988), «Il ditirambo come spettacolo musicale. Il ruolo di Archiloco e di Arione», in B. Gentili e R. Pretagostini (eds.), La Musica in Grecia. Roma-Bari, Laterza, 123-131.

Reid, J. D. (1993), The Oxford Guide to Classical Mythology in the Arts, 1300-1990s. Vol. I. New York-London, Oxford University Press, 214215 (s.v. Arion).

Richter, G. M. A. (1984, 2a ed.), The Portraits of the Greeks. Abridged and revised by R.R.R. Smyth. Oxford, Phaidon. 
Robertson, M. (1978), La peinture grecque. Trad. O. Sirén. Genève, Albert Skira

Roblot-Delondre, L. (1917-1919), «Les sujets antiques dans la tapisserie», Revue archéologique 5, 296-309; 7, 129-150; 9, 48-63; 10, 294-332.

Rocha Pereira, M. H. (2009), Vasos gregos: mensagem de arte e cultura. Orgs. M. F. S. Patrocínio e C. Teixeira. Évora, CHAIA.

Russell, D. A. (1973), Plutarch. London, Duckworth.

Schamp, J. (1976), "Sous le signe d'Arion», Ant.Class 45, 95-120.

SoAres, C. I. L. (2003), A morte em Heródoto. Valores universais e particularismos étnicos. Lisboa, FCG/ FCT.

Stevens, B. (2009), «Pliny and the Dolphin - or a Story about Storytelling», Arethusa 42, 161-179.

VAN Der Stockt, L. (2005), «Plutarch and Dolphins: Love Is All You Need», in J. Boulogne (ed.), Les Grecs del'Antiquitéet les animaux: le cas remarquable de Plutarque. Lille, Editions du Conseil Scientifique de l'Université Charles-de-Gaulle Lille 3, 13-21.

Wolf, N. (2006), Albrecht Dürer (1471-1528). O génio do Renascimento alemão. Trad. port. M. Neto. Munique, Taschen. 
Woodford, S. (1986), An Introduction to Greek Art. London, Duckworth.

Zimmermann, B. (1992), Dithyrambos. Geschichte einer Gattung. Göttingen, Vandenhoeck \& Ruprecht. 


\section{Anexo I - A aventura de Aríon salvo por UM GOLFINHO}

\section{FONTES LITERÁRIAS PRINCIPAIS}

\section{Heródoto, Histórias 1.23-24. Traduçáo de José Ribeiro Ferreira (1994, 68-70)}

23.1. Periandro, o que revelou a Trasibulo o oráculo, era filho de Cípselo. Periandro tornou-se tirano de Corinto e, durante a sua vida, - dizem os Coríntios e confirmam-nos os Lésbios - foi testemunha de um extraordinário prodígio: Aríon de Metimna levado ao Ténaro no dorso de um golfinho, ele que era um citaredo náo inferior a qualquer outro da sua época, o primeiro dos homens, de que temos conhecimento, a compor ditirambos, a dar-lhes esse nome e a fazê-los executar em Corinto.

24.1. Este Aríon, que viveu a maior parte do tempo junto de Periandro, contam eles, foi tomado do desejo de navegar para a Itália e para a Sicília e, depois de ganhar muito dinheiro, quis voltar de novo a Corinto. 2 . Partiu então de Tarento e, como não confiava em mais ninguém senão nos Coríntios, contratou um barco de marinheiros Coríntios. Estes, no alto mar, maquinaram lançar Aríon pela borda, para se apoderarem das riquezas. Ao ter conhecimento disso, ele implorou-lhes piedade: entregava as riquezas, mas pedia a vida. 3 . Não conseguiu, todavia, persuadi-los; pelo contrário, os marinheiros intimaram-no ou a suicidar-se, para alcançar uma sepultura em terra, ou a atirar-se ao mar, 
de imediato. 4. Reduzido a tais apuros, Aríon pediu, visto assim terem decidido, que lhe permitissem, de pé, na coberta do barco, cantar com todo o seu traje de gala. 5. Depois de cantar, acedia em pôr fim à vida. Encantou-os a ideia de poderem ouvir o melhor cantor entre os homens e retiraram-se da popa para o centro do barco. Aríon pôs todos os seus enfeites, pegou da cítara e de pé, na coberta, executou o canto órtrio. Terminado este, lançou-se ao mar, tal como estava, com todos os enfeites. 6. E enquanto eles navegavam para Corinto, conta-se que um golfinho tomou o poeta sobre o dorso e levou-o para o Ténaro. Apeado em terra, regressou a Corinto com os adornos e, uma vez aí chegado, relatou tudo o que aconteceu. 7. Periandro, por incredulidade, mantém Aríon sob custódia, sem o deixar ir para lado nenhum, mas deu atenção aos marinheiros. Logo que estes apareceram, chamou-os e informou-se se tinham algo a dizer a respeito de Aríon. Estavam eles a dizer-lhe que estava são e salvo em Itália e se encontrava bem, quando o deixaram em Tarento, e eis que lhes aparece Aríon, como estava vestido quando se lançou ao mar. E eles, consternados e convencidos, não puderam negar mais. 8. Este relato contam-no os Coríntios e os Lésbios e de Aríon existe uma estátua de bronze no Ténaro, que representava um homem no dorso de um golfinho.

Plutarco, $O$ Banquete dos Sete Sábios 18.160e-19.162b. Tradução de Delfim Ferreira Leão (2008, 109-113)

18. Gorgo contou então que havia celebrado 
sacrifícios durante três dias, sendo que o último comportava uma vigília nocturna, danças corais e $\mathrm{F}$ jogos junto à praia. A lua brilhava sobre o mar e, embora não soprasse vento e houvesse pelo contrário grande calmaria e quietude, começou a avistar-se ao longe uma crispação que avançava em direcção ao promontório, acompanhada de escuma ligeira e de um bramido intenso devido à ondulação que produzia em volta, a ponto de todos acorrerem, maravilhados, para o lugar onde se esperava que tocasse em terra. E antes que, devido à grande velocidade, pudessem imaginar o que se avizinhava, apareceram diante dos nossos olhos golfinhos: uns em grupo e dispostos em círculo, outros que se dirigiam para a zona mais chã da praia, outros ainda que ficavam atrás, como se formassem uma escolta. Ao 161A centro, emergia à superfície do mar a massa indistinta $\mathrm{e}$ indefinida de um corpo que era transportado, até que os golfinhos se juntaram todos e acostaram em conjunto, depositando em terra um homem que respirava ainda e se mexia. Em seguida, os golfinhos retomaram a direcção do promontório, dando saltos ainda maiores, como se estivessem a brincar e a fazer acrobacias devido a uma alegria inexplicável.

- Muitos de nós - continuou Gorgo ficaram tomados de pânico e fugiram do mar a correr, mas uns quantos (entre os quais me contava eu) encheram-se de coragem e aproximaram-se o suficiente para reconhecerem o citaredo Aríon, que conseguiu pronunciar o próprio nome, além de que era facilmente B reconhecível pelas roupas. Com efeito, envergava 
ainda o traje de cerimónia que costumava usar quando cantava em concursos, fazendo-se acompanhar da cítara. Transportámo-lo em seguida até uma tenda, pois não parecia ter sofrido qualquer ferimento, embora estivesse visivelmente moído e esgotado pela velocidade e rapidez do transporte. Depois, escutámos da boca dele uma história incrível para toda a gente, menos para nós que tínhamos assistido à sua conclusão! Narrou então Aríon que havia tomado, algum tempo atrás, a decisão de sair de Itália e que a recepção de uma carta de Periandro veio acentuar ainda mais esse propósito. Assim, quando atracou no porto um navio mercantil proveniente de Corinto, subiu de imediato a bordo e fez-se ao largo. Decorridos três dias de vento favorável, Aríon teve o pressentimento de que os marinheiros projectavam tirar-lhe a vida e ficou depois a saber pelo piloto - o qual the confiou essa informação em segredo - que eles estavam decididos a pôr o plano em acção nessa mesma noite. Ora encontrando-se ele sozinho e sem possibilidade de obter auxílio, decidiu dar seguimento a uma ideia de inspiração divina: adornar-se e, estando embora vivo, endossar como vestimenta fúnebre o seu traje de cerimónia e entoar um último canto em honra da vida, agora que estava para terminá-la, mostrando com este gesto uma nobreza não menor que a dos cisnes. Ora uma vez concluídos estes preparativos, anunciou que desejava entoar um dos seus hinos a Apolo, a fim de acautelar a própria segurança, a do barco e a de todos os tripulantes. Tomou então um lugar na ponta do barco, junto à popa, principiou por modular como prelúdio 
uma invocação aos deuses marinhos e depois pôs-se a entoar o hino. Quando não havia ainda chegado a meio da ode, o sol começou a mergulhar nas águas e

D a costa do Peloponeso a aparecer no horizonte. Então, os marinheiros decidiram não esperar pela noite e avançaram com intenção de matá-lo. Ao ver os punhais desembainhados e o piloto que já cobria os olhos, ele tomou balanço e lançou-se borda fora, para o mais longe possível do barco. Antes que o corpo ficasse completamente submerso pelas águas, alguns golfinhos puseram-se a nadar debaixo dele e trouxeram-no à superfície. De início, ficou completamente confuso, ansioso e atarantado. Porém, ao constatar a facilidade com que o transportavam, ao ver os golfinhos agrupados em grande número, amigavelmente, à sua volta, assumindo à vez aquela tarefa, como se fosse obrigatório nela tomar parte e a todos dissesse respeito, e ao ter a sensação da velocidade a partir do facto de o barco

E ter ficado bem para trás, sentiu nascer dentro de si contou ele — não tanto o receio perante a morte nem propriamente um desejo de viver, mas antes o orgulho de poder salvar-se (aparecendo como um homem caro aos deuses) e desenvolver uma crença inabalável no respeitante à divindade. Por outro lado, ao contemplar o céu repleto de estrelas e a lua a elevar-se, cintilante e límpida, ao mesmo tempo que o mar se apresentava a toda a volta sem ondas, como que oferecendo um trilho aberto para lhes servir de caminho, pensou para consigo mesmo que a Justiça não possui um olho apenas, mas que com estes múltiplos olhos a divindade observa em 
todas as direcçóes o que vai sendo praticado, tanto em terra como no mar. Disse ainda que, através destas cogitaçôes, ia encontrando lenitivo para suportar a fadiga que já se abatia sobre o seu corpo. E por fim, quando lhes apareceu pela frente o promontório, íngreme e alcantilado, os golfinhos evitaram-no facilmente, descrevendo uma curva sobre a superfície das águas, e foram nadando ao longo da praia, como se estivessem a conduzir em segurança um barco até ao porto. Nessa altura, Aríon compreendeu perfeitamente que o seu resgate fora conduzido por um deus.

- Depois de Aríon haver relatado estes $162 \mathrm{~A}$ pormenores, - continuou Gorgo - perguntámos-lhe onde iria, em sua opinião, o barco atracar. Ele respondeu que seria certamente em Corinto, mas que, em todo o caso, ainda tardaria muito a chegar. Com efeito, depois de, ao fim da tarde, se haver lançado borda fora, ele achava que o teriam transportado durante não menos de cinquenta estádios; e entretanto, a calmaria teria retido o navio.

Ainda assim, Gorgo esclareceu que logo se informou acerca do nome do armador e do piloto, bem como do emblema do barco, tendo também enviado navios e soldados para montarem guarda aos locais de desembarque. Quanto a Aríon, tinha-o trazido consigo às escondidas, a fim de evitar que os culpados, ao tomarem conhecimento prévio do seu salvamento, se pusessem em fuga. $\mathrm{Na}$ verdade, tudo parecia ter acontecido segundo os desígnios da divindade: com efeito, logo à chegada a Corinto, ficara a saber que o 
barco havia sido entretanto arrestado pelos soldados, que tinham capturado igualmente os comerciantes e os marinheiros.

19. Periandro deu então instruçôes a Gorgo para que partisse de imediato e fosse meter aquelas pessoas na prisão, de maneira a ninguém ter acesso a elas e não as poder informar de que Aríon escapara são e salvo.

\section{Cláudio Eliano, Natureza dos animais $12.45=$} fr. 939 PMG. Traduçáo de Luísa de Nazaré Ferreira $(2008,23)$

Supremo deus, senhor do mar, Poséidon do tridente de ouro, que a terra sacode com vagas ondeantes, à tua volta, com suas barbatanas, os aquáteis seres dançam em círculo em lances rápidos, saltando com agilidade, criaturas de focinho chato, colo cerdoso, velozes, golfinhos amantes da música, prole marinha das divinas filhas de Nereu, os quais Anfitrite gerou: eles é que para a terra de Pélops me levaram, rumo ao cabo Ténaro, andava eu errante no mar da Sicília, acolhendo-me em seus dorsos curvos, abrindo sulcos na planura de Nereu, passagem não trilhada, quando homens pérfidos me lançaram da mareante [côncava nau para as ondas purpúreas do mar. 


\section{Anexo II - Plutarco e a arte ocidental A influência da obra de Plutarco na tapeçaria FLAMENGA}

A determinação segura das fontes literárias de uma tapeçaria ou conjunto de tapeçarias (armação, série$\left.^{1}\right)$ não é tarefa acessível, como dissemos acima, nem tão pouco o é a identificação das temáticas ou peças que possam ter sido inspiradas pela extensa obra de Plutarco. $\mathrm{Na}$ Idade Média, os mestres tapeceiros recolhiam habitualmente de manuscritos os assuntos a tratar, mas no Renascimento são os livros impressos e ilustrados com gravuras que lhes vão fornecer as principais fontes de trabalho. A história antiga fora sempre um tema favorito, mais ainda do que a mitologia clássica, com a qual era muita vezes combinada. No século XVI, porém, com a impressão dos originais e sucessivas traduçôes dos autores latinos e gregos - como Tito Lívio e Plutarco - os episódios da história antiga, em especial de Roma, e das vidas e feitos de grandes líderes políticos e militares alcançam uma popularidade extraordinária. A divulgação deste legado autêntico vai permitir ainda a valorização da organização cronológica dos assuntos de natureza histórica, um aspecto de grande importância na concepçáo das séries de tapeçarias. Nas palavras de L. Doblot-Delondre $(1917,302)$ : «Ce fut le grand titre

${ }^{1}$ A distinçáo que se faz por vezes entre «armação» (fr. tenture, conjunto de panos murais ligados entre si pelo tema) e "série» (armação reproduzida várias vezes) nem sempre é considerada pelos especialistas e os termos são também usados como sinónimos. 
de gloire des humanistes florentins d'avoir rétabli la chronologie dans l'histoire; avec eux les faits historiques reprennent leurs valeurs relatives, les héros de l'antiquité leur place réelle dans l'histoire et les délicieuses légendes de la mythologie grecque deviennent des fictions aimables qui seront la source principale de l'inspiration des artistes de la Renaissance.»

Para a redacção desta breve nota baseámo-nos, em primeiro lugar, no clássico La tapisserie flamande $d u$ $X V^{E}$ au XVIII siècle, de Guy Delmarcel, que menciona o nome de Plutarco a propósito das seguintes séries:

- História de Rómulo e Remo, fundadores de Roma, a partir de Tito Lívio e da Vida de Rómulo, de Plutarco; foi um dos temas romanos mais representados na tapeçaria flamenga do século XVI;

- César e Cleópatra; a Vida de César de Plutarco é uma das fontes;

- História grega ou Homens célebres segundo Plutarco (Hommes célèbres d'après Plutarque).

Embora esta série não seja mais importante do que as que tratam Rómulo e César, tem mais interesse para nós por se basear directamente na tradução de Jacques Amyot das Vidas Paralelas. A realização dos cartôes foi encomendada em 1711 ao pintor Victor Janssens (Bruxelas, 1658-1736), tarefa que lhe viria a trazer grande fama, pela sociedade constituída pelos irmãos Urbain e Daniel II Leyniers e Henri II Reydams, em cujas oficinas foram executadas as peças. Cada tapeçaria era dedicada a uma personalidade da Antiguidade e destinavam-se a um círculo de clientes militares. As obras, das quais se 
preservam várias ediçôes, todas realizadas nos mesmos ateliês de Bruxelas, devem certamente ter agradado, visto que o número de assuntos aumentou de oito, em 1715, para onze, em 1734. Nas pp. 328-329 do livro de Guy Delmarcel é reproduzida a tapeçaria $O$ sacrifício de Aristides $(370 \times 420 \mathrm{~cm}$ ), que representa o político ateniense a oferecer um sacrifício junto do monumento funerário de um general ${ }^{2}$.

Destas breves linhas se conclui que é mais fácil identificar as peças inspiradas nas Vidas Paralelas do que nos Moralia, que devem ter existido seguramente. Por conseguinte, é de supor que outras séries, nomeadamente as que integram as colecçóes dos museus nacionais, se baseiem, pelo menos em parte, em Plutarco.

No que respeita aos temas acima referidos, registese que o Palácio Nacional de Sintra possui uma tapeçaria fabricada na Flandres no século XVI, de assunto não identificado, que pertenceu a uma série da História de Júlio César ${ }^{3}$ Quanto é do nosso conhecimento, tratase da única peça alusiva ao chefe romano, embora as colecçóes públicas possuam outras tapeçarias que representam episódios, ainda não identificados, da história de Roma (por exemplo, o Museu de Francisco Tavares Proença Júnior, de Castelo Branco).

Estão muito mais representados nas colecçóes públicas de Portugal dois ciclos temáticos que foram extremamente famosos na Europa ocidental:

- a História de Marco António, da qual se conservam

${ }^{2}$ Delmarcel (1998) 155, 231, 312, 328, 333, 367, 369.

${ }_{3}^{3}$ Vide Mendonça (1983) 182-183; http://pnsintra.imc-ip.pt/ pt-PT/coleccoes/HighlightList.aspx (acedido em 25/07/2010). 
várias tapeçarias no Museu Nacional de Arte Antiga e no Palácio dos Duques de Bragança (de Vila Viçosa) ${ }^{4}$.

- a História de Alexandre, o Grande, que integra as colecçóes dos mesmos museus, mas também do Museu de Lamego, do Palácio Nacional da Ajuda e do Palácio Nacional de Mafra.

$\mathrm{Na}$ análise destas peças, Maria José de Mendonça regista $(1983,56)$ que as tapeçarias Alexandre acaba de domar Encéfalos [sic] e A Batalha de Granico do Museu Nacional de Arte Antiga, que pertencem à armação História de Alexandre, realizada no séc. XVIII a partir do pintor francês Charles Le Brun (1619-1690), se baseiam directamente em Plutarco5. É quase certo que muitas outras tapeçarias se inspiram na sua obra, quer nas Vidas Paralelas quer nos Moralia.

${ }^{4}$ Vide Mendonça (1983) 49-56, 216-217.

${ }^{5}$ Cf. R. Vanhoren (1999), «Tapisseries bruxelloises d'après les modèles de Charles Le Brun: L'Histoire d'Alexandre le Grand», in C. Arminjon et N. de Reyniès (dir.), La tapisserie au XVII siècle et les collections européennes. Paris, Éditions du Patrimoine, 61-68. 